\begin{tabular}{|c|c|}
\hline DOSSIÊ & $\begin{array}{l}\text { THE ANATOMY OF } \\
\text { MEDIATIZED NEWS } \\
\text { BROADCASTING: } \\
\text { metamorphoses and multiple narratives }\end{array}$ \\
\hline $\begin{array}{r}\text { Copyright } \odot 2012 \\
\text { SBPjor / Brazilian } \\
\text { Association } \\
\text { of Journalism } \\
\text { Researchers }\end{array}$ & $\begin{array}{l}\text { FABIANA PICCININ } \\
\text { Universidade de Santa Cruz do Sul } \\
\text { DEMÉTRIO DE AZEREDO SOSTER }\end{array}$ \\
\hline
\end{tabular}

ABSTRACT - This article discusses mediatization in news journalism, which is characterized by the institution, in current times, of a new "place" for the media. From this standpoint, they are no longer regarded as mere media, but as structuring elements of a new communicational bios. In the course of society's transition from the media towards a mediatized society, news production practices become complex and process practices, as well as narrative and content distribution forms emerge, that are distinct from those seen until then. Television news broadcast emerges, therefore, in a new format, made up of the cluster of diverse media that refer to such programs, demanding new identification and recognition protocols. These changes will be examined as they relate to the news telecasts TV Folha, of TV Cultura, based on four movements resulting from the mediatization process in journalism: self-referentiality, co-referentiality, decentralization and dialogy.

Keywords: Television news broadcasting. Mediatization. Transformations. Multiple narratives.

\title{
DA ANATOMIA DO TELEJORNAL MIDIATIZADO: metamorfoses e narrativas múltiplas
}

RESUMO - Este artigo discute a midiatização do jornalismo, que se caracteriza por instituir, na contemporaneidade, um novo lugar às mídias. Por este viés, elas não são mais vistas apenas como meios, mas como elementos estruturantes de um novo bios comunicacional. Assim, nessa passagem da sociedade dos meios para a sociedade midiatizada, complexificam-se práticas de produção de notícias e instauram-se processualidades e formas de narrar e de distribuir conteúdos distintas do que se tinha até então. O telejornal emerge, portanto, em um novo formato de programa de notícias na TV, integrado pelo conjunto das mídias que a ele se referem, requerendo novos protocolos de identificação e reconhecimento. Para efeito deste estudo, essas mudanças serão observadas no telejornal TV Folha da TV Cultura a partir dos quatro movimentos resultantes do processo de midiatização do jornalismo: autorreferencialidade, correferencialidade, descentralização e dialogia.

Palavras-chave: Telejornalismo. Midiatização. Transformações. Narrativas múltiplas.

\section{LA ANATOMÍA DEL NOTICIARIO TELEVISIVO MEDIATIZADO: metamorfosis y narrativas múltiples}

RESUMEN - Este artículo discute la mediatización del periodismo, que se caracteriza por instituir, en la contemporaneidad, un lugar nuevo para los medios de comunicación. Desde esta perspectiva, ya no son vistos apenas como medios, sino como elementos estructurantes de un nuevo bios comunicacional. En ese trânsito de la sociedad de los medios a la sociedad mediatizada, las práticas de producción de las noticias se hacen cada vez más complejas y se instauran procesos y formas de narrar y de distribuir contenidos que son diferentes de los que existían hasta hace poco tiempo. El noticiario televisivo adquiere, por lo tanto, un nuevo formato de programa de noticias en la TV, integrado por el conjunto de los medios que con él se relacionan, exigiendo nuevos protocolos de identificación y de reconocimiento. Se observarán estos cambios en el telediario TV Folha, del canal Tv Cultura, a partir de los cuatro movimientos resultantes del proceso de mediatización del periodismo: autorreferencialidad, correferencialidad, descentralización y dialogismo.

Palabras clave: Periodismo televisivo. Mediatización. Transformaciones. Narrativas múltiples. 


\section{From the scenario to the journalistic narrative}

The investigation into the metamorphoses brought into television journalism demands a mapping out, in principle, of the place of signification of the mediatic instruments in relation to the presentday changes. One observes today's society, affected by profound technological immersion, particularly since the second half of the $20^{\text {th }}$ century, and the number of changes related to this phenomenon, such as the rapid pace of processes, the complexification of concepts, as well as new logical mind frames both in thought and speech.

Such transformations will be analyzed from a sociotechnodiscursive angle as an investigation strategy for the relation interposed between the procedures of production and circulation of news. These are perceived as dimensions that help make up a wide range of changes, which both affect and are affected by all the other elements that feature in modern times. The option for circulation can be explained, given that from a perspective of mediatization,

\footnotetext{
(...) circulation ceases to be a kind of "passage point" where meanings between speech producers and speech receivers would be automatically expressed, and instead becomes an "articulation point", where an interactional enunciative activity is developed, in which the meanings emerge according to logics of indetermination. (FAUSTO NETO, 2010, p 45)
}

In other words, the mediatization phenomenon now looks at the media from a new logic standpoint in which communication devices play a role that transcends that of mediators of human activity, to help compose a new ambience, which is noticeable, among other factors, from the development of new discursive and operational logic sets (SOSTER, 2008, 2009).

Occupying that central stance, the media consequently shapes a new communicational ecology (GOMES, 2006), establishing a new bios (SODRÉ, 2006), which is affected above all by the virtualizaton of interactions. Adopting a similar perspective, Hjarvard (2012) adds that once this new integrative scenario of the media has been established, it is that perspective that renders it possible and necessary to understand the way those new relations between media and society generate new social/mediatic/cultural/technological practices. Fausto Neto (2008, p. 93) notes that: 
The media lose this auxiliarity role and develop into a forming reference in society's makeup, as well as in interaction processes between institutions and social agents. The expansion of mediatization into an ambience, with technologies promoting new ways of living, with interactions affected and/or shaped by new strategies and organization forms, would cause everyone - producers and consumers - to share the same reality: that of FLUXES, which would allow us to know and recognize at the same time. Nothing would be excluded from the boundaries of this makeup, given that there would be no object whatsoever yet to be represented, for everything would be included in the multiple relations and codeterminations, to be manifested in the form of existence of this environment of flux and send/resend.

It is, therefore, a question of looking at what changes will occur, given this new configuration, in television news broadcasting and related activities, as it leaves its mediating role, through which society speaks/is spoken of, to become, itself, the "speaker". That is how television news broadcasting is understood, which in turn establishes in its narratives and in the ever-changing forms of its speech, the nature of a given society at a given time, and its mutations, which will be the investigation conduit towards a better view of this new moment and its configurative expression.

Thus, in view of these changes, the program, as an expression of the all the media, goes beyond its original meaning and, ultimately, its ethicity' ${ }^{\prime}$ of means, in a proposition by Killp (2003), once it ascends to the integrative level of the present-day scenario, offering a speech with which people also establish relations, make decisions, organize their experiences and, ultimately, attribute meanings to life. In other words, in this ever-changing scenario, the concept and identification of what television news broadcasting is about keep suffering metamorphoses that influence their actions and language, and which gradually result in a configuration that is new and, in turn, very detached from what was originally acknowledged as constituting specific traits of television news broadcasting in the course of its 60 years.

\section{The Mediatization of television news broadcasting}

As regards journalism, the practice occupies a place of its own in the mediatization process. Since the mediatic devices through which it usually conveys its offers of meaning to society - television, radio, newspapers, websites, etc. - are mediatizing vectors for all the reasons shown, they ultimately both affect and are affected by these dynamics. The result is their mediatization (SOSTER, 2009). When this occurs, when 
journalism as a practice of meaning is mediatized, it is reconfigured and becomes more complex, thus requiring its own interpretive grammars.

Soster (2002 b) suggests that the mediatization of journalism can be observed as such in four identifiable movements - which will be further discussed here -, seen in the circulation of the means and their contents. They are self-referentiality, co-referentiality, decentralization and dialogy. It is in this locus of movement - that of circularity - of a sociotechnodiscursive nature that possibilities of "(...) new interactions are established, within the scope of mediatization, in the journalistic practices" (FAUSTO NETO, 2012, p. 55) of those who watch the news show TV Folha, aired by TV Cultura, and which fits into some reflective analysis in progress of those changes observed in news broadcasting based on that program².

The news show, first aired in March of 2012, and produced jointly by the newspaper Folha de São Paulo and TV Cultura, is broadcast on Sundays at 7:30pm, lasting 30 minutes. The segments are, as a rule, culture (illustrated), behavior (daily Life), sport, and police, each of which frequently feature topics already included in their printed medium, the daily newspaper Folha de São Paulo. Every news broadcast, in turn, is made available on the program's site at the same time it is aired, so that it can be watched on the web in real time or, at a later time, via a web link $^{3}$

Television news broadcasting was chosen as it is a clear sample of the present-day metamorphoses suffered by on-screen journalism, in form and content, as shall be discussed progressively in this analysis. From this standpoint, the program in question does display a certain experimentalism in language - born of this reconfiguration - as well as in the delivery of its contents, rendering it illustrative of the movements of present-day television news broadcasting. Such movements are rendered possible by transformations brought about by the mediatization phenomenon.

In this sense, the analysis begins by observing the selfreferentiality displayed on the program, the foremost trait of the complex phenomenon of journalism mediatization, regarded as the present-day media's characteristic of repeatedly referring to its own operations. Selfreferentiality occurs when, for instance, the program refers to itself in its offers of meaning, be it through explicating its operations or through textual marks as a strategy, in one case among others, to display credibility (FAUSTO NETO, 2006).

In the case of journalism as it is operated on television, one 
considers, therefore, practices and discourses derived from that specific configuration, which deals with news in an audiovisual device, and the latter in the vehicle/means television. Thus, Cannito's (2010, P. 27) standpoint seems applicable: television is also a means of exhibiting content, viewed by extension as the medium where those contents can be socialized. Television would then require that we regard it as possessing a language of its own, from which on-screen formats derive in view of the use viewers make of its contents.

The concept of television news broadcasting used as a reference point in order to pinpoint change, derives from a consensus shaped during the 60 years of its existence in Brazil and is, as it turns out, imbued with its significance solidly established by the use viewers make of it. In other words, it is a program that, once inserted in a network's grid, deals with contents that are either referential or phatic, as opposed to the fictitiousness of other genres of the grid, which has, as a rule, a preset time, length and name. It is one of the programs that generate more prestige than revenue and which, as a result, every television channel airs at least once a day (BUSTAMANTE, 1999)

Hence, TV Folha has proven to be an evident application of such transformations in face of this original model, rendering clear the feature of self-referentiality. The program's originating idea focuses, according to D'ávila (2012), on taking advantage of the high quality and standing enjoyed by Folha de São Paulo's newsroom staff in order to benefit other means, such as television. Televised media, in this instance, presents itself on the device known as printed paper, in a clear movement of selfreferencing.

The same logic applies to the structuring of news reports. As regards television and the imparting of news stories, one must bear in mind that the vehicle offers credibility and seduction by means of images in movement. In addition, images can appeal to a vaster, more diverse viewership, because they do not require mastery of linguistic codes or payment for the contents, in the case of open-channel television.

On TV Folha, the evidence of self-referentiality is noticeable in the dynamics marked by speech and image, appearing focused on itself, as both the appeal of the narrator and the linguistic resources themselves - such as the iconic image as witness's evidence - are of great impact. For instance, there is the widely accepted practice of bringing the backstage production into the contents of the news stories/reports, instituting by extension the presence of the reporter and, at times, the film reporter.

The movement was not only generally absent from newscast 
programs until then, but also "frowned upon" for presupposing protagonists and, by extension, the subjectivity of narrative agents, going against the desirable guidelines of objectivity and impartiality, as well as the suppression of the voice reporting the story. In the case of TV Folha, the public are told that the program "did the story" and brought it to its viewers, thus familiarizing them with production processes, adding credibility to situations involving news reporting in which the agents involved report the news, as well as the news making processes.

In a different sense, self-referentiality can be perceived due to the vast technological immersion experienced in modern times, showing the apparent influence of the fast pace dictated by the production and publishing of web news, which is adopted by television and creates new procedural routines in the media system. Once again, it is the backstage that stands out, because it validates/endorses veracity of fact and informality of language, as the news broadcasting shows take over the newsroom - "the floor of the shop" - turning it into an integrated set of the news program. This is where reporters comment on production process, in settings outside the VT they made.

There is thus a reference for how the journalistic agent can speed up the news-reporting process, from the moment newsworthy events happen to the moment they are viewed. On TV Folha, the newsroom is an integral part of both the news reporting and the opening images, which show the news staff working in the news production process. The set of the program is simply the news anchor at their desk, framed in such a way as to show their colleagues also at work in the background.

The telecast, therefore, operates so as to create new reading contracts from that very first image, once it incorporates what was until then concealed from viewers. The disregard for the objective logic concerning the suppression of the speech agent pushes the program towards a more informal narrative (PICCININ, 2007), inciding upon the program, as Becker and Teixeira have noted:

\footnotetext{
(...) a suppression of differences between news reporting and news events, between speech acts and social facts, reaffirming the standing of television news broadcasting programs as actual spaces of social experience, nor of mere performance; simulating the viewers' access not only to studios and news crews, but to reality itself, comprised of a technically naturalized narrative. (BECKER; TEIXEIRA, 2009, p.235)
}

Such referentiality takes on a different nuance when news reporting, upon being aired on television, suffers metamorphoses in both speech and modus operandi, on account of co-reference. Co-referentiality 
is also born of the environment of profound techno-mediatic immersion experienced today, in view of the fact that journalistic institutions take advantage of their peers in order to validate their own work as well as that of others. In such cases, news agendas, reports, and major news coverage, all start from the printed page, radio, TV, or the web. These vehicles reach out to other media, creating a kind of uninterrupted circularity of discursive feedback within the system. In other words, if in face of present-day multiple mediatic narratives, journalism - and, in it, news broadcasting - seeks to validate itself by means of self-referentiality, which confers, above all, credibility upon itself. The horizontal process utilized with its peers also moves in the same direction, albeit towards slightly different goals.

On TV Folha, the co-referencing movement takes place through interlocution between the media, resulting in a "unique product", thus characterizing an operational closing of systemic nature (SOSTER, 2009). In the printed paper, available on the streets early Sunday morning, one can find references to the contents of the evening audio-visual news cast. When the program comes to a close, one sees the second institutional co-reference: the TV program refers to the news contents available on the web, as well as pointing to the possibility of web user-site interaction regarding those contents. Such movement also takes place when the news cast refers to the printed edition to be circulated on the following morning.

This movement seeks, primarily, the operational closing of the mediatic-communicational micro-system comprising the vehicles TV Folha and Folha de São Paulo, as well as the social networks that intercommunicate with them. A second stage, due to this movement, is identity strengthening, which allows a) distinction from other systems, and the ensuing $b$ ) strengthening of bonds with those who access their system. It is worthy of note, in Luhmann's (2009) perspective, that the operations of a given system are co-referential in nature, that is, turned towards themselves and carried out in such a way as to reinforce their own system by means of reducing the complexity within.

\section{Less hierarchy and more hybridism}

Decentralization, the third trait of mediatized journalism identified by Soster (2009), is clear in today's journalism, whenever it operates in a rhizome condition made possible especially by the technological apparatus available to network relations (CASTELLS, 
2002). The rhizome severs the hierarchical standing between mediatic institutions, weakening whatever differences there may be - whether they concern hegemony or significance. Dilution of the diagram's axiom - from a hierarchical connective point of ascendancy over others, is a characteristic of the network.

In fact, at present, technological immersion and converging practices made possible by the digital world are conducive to joint network operations in diverse types of media. The choice of rhizometype over axiomatic media in new socio-techno-discursive environs is essential to journalism's mediatization. Such operations give rise to original processes due to their relation to possibilities of convergence, viewed here through Jenkins's perspective, as:

\begin{abstract}
(...) the flow of contents through multiple media vehicles to cooperation between multiple mediatic markets and to the migratory behavior on the part of both consumers and means of communication, who/which go almost anywhere in search of entertainment. (...) In the realm of media convergences, every story of any import is told, every brand is sold and every consumer is courted by multiple media devices (JENKINS, 2008, p. 27).
\end{abstract}

In other words, the notion of centralization is being discussed in response to the hegemony of the medium that "originates" content in relation to other media that offer the same programming. It is important to appreciate that non-cable channel news broadcast programs, not long ago, enjoyed unquestioned privilege in any grid, firstly for their exclusiveness, as well as for their superior standing in relation to other media that might refer back to them.

In the case of TV Folha, the possibility of convergence allows for other wider discursive limits which are so integrated in the "newscast package" as to be perceived as a whole, or as something greater than just TV as an audio-visual device. One example is the network's website, but it is also the case with social network associates. While any given technique or device produces and elicits a certain way of referring to and delivering news, digital and non-digital technologies today result in a TV program that evolves and gradually moves away from its original model to become a combination of all related narratives on different media.

TV Folha was created, according to D'ávila (2002), owing to a decision by part of the network and its printed paper to diversify their contents, resulting in horizontality in relation to the other devices in the network. They then gradually become as important in the makeup of the news narrative as the "original" program, which could be taken here to denote the news program, provided the notion of "original" program is 
what motivates this review. According to Piccinin (2012):

\begin{abstract}
In face of mediatic convergence, which comprises several forms of content delivery as well as mutual language influence on each of the three devices, it would be more prudent to argue that the program/product is all of that at once and now, allowing us to perceive that we are witnesses to the birth of a new format for printed newspapers, news programs and teleweb. In other words, producing symbiosis and a hybridization of journalistic narratives, as discussed in this text and characterized, therefore, as a journalistic mediatic manifestation that is typical of our time, of a mediatized journalism that becomes decentralized, weakening hierarchy between different media, of no defined or definitive boundaries, and which redefines itself, generating new formats. (Piccinin, 2012 b, p. 10).
\end{abstract}

Such demands are also important to professionals in this area, given that they are expected to be able to master both the esthetic implications of those new formats and devices, as well as carry out the operational manipulation of production and delivery of products on other devices, in this case in relation to the "original device"; television. Since these movements do not occur independently from each other, it is important to bear in mind that decentralization reinforces both selfreference and co-reference, in the same manner that decentralization makes of these "folds" one whole entity, as opposed to the model once used, the one that still regards other delivery platforms as peripheral.

The world of news production in broadcast programs also leans toward a decentralized operation, as everyone has access to all contents being produced, thus abolishing that axiomatic place where there were once several reporters and crews subordinated to an editor. As technologies enable crews not only to collect news material, but also to edit it, some decide to do so, delivering "ready" products, as is the case with international coverage crews and one-man crews, reporters who are thus submitted to the experiences of the "reporter-bee"4.

\begin{abstract}
These tools, introduced in the routines of a multimedia journalist, or a mobile one, will develop into a multiplatform production, requiring a multitask professional with skills to deal with various digital technologies in a production flow that is more dynamic, which, in turn, demands that that professional respond more promptly to the content distribution process while still in a phase of news checking and production, as in live broadcasts for websites or for a TV channel via $3 \mathrm{G}$ cell, delivery of parts of production in the form of text, visual flashes or even videos, among other conditions imposed. It is a change in flow as well as routine (SILVA, 2009, p.9).
\end{abstract}

Although thorough information about news production is not given here, it is possible to state that the way reporters stand as sources of their own news stories also has to do with the notion that, to some extent, they operate throughout the whole process, from the assignment 
meeting to the finished edition, though this is not a general rule. For that reason, decentralization of media journalism is visible in the new forms of relationship between the world of production, product delivery of TV news program contents and its viewership.

Much has been said about the place and possibility of interactivity that social networks and 2.0 web platforms offer the public, not only in terms of contribution and collaboration in the production of contents and the repercussions of those contents in the form of comments and posts, but also in terms of sharing that material and the re-creation of those same contents. A new place is made available to the viewer, now a user of digital technologies and able to contribute videos, photos or information to news broadcast programs, given the popularization of image-gathering with cameras and mobile phones, available to news production professionals as well as viewers.

\begin{abstract}
So, it is clear that the culture of convergence is reconfiguring news production and news consumers, contents, genres, languages and mediatic narratives. New possibilities arise each day, and happen mainly due to collective work, born of same-interest communities present in the major social networks on the web: Facebook, MySpace, Orkut, Sonico, Tweeter, Fickr and Linkedln.Together, they draw about eight hundred million users and followers, all discussing, informing, misinforming, building, destroying, communicating (CABRAL et al, 2011, p. 8).
\end{abstract}

As TV Folha is available on the internet, it may be shared and commented on through social networks, enjoying the status of end product. At the same time, it may also receive material and suggestions from viewers via interactive resources in the network, even though these seem to be exploited on the more immediate levels with regard to the program. These possibilities gradually take exclusive control over the contents away from the vehicle, marking a change from axiom to rhizome.

Lastly, dialogy, being a trait of journalism's mediatization (SOSTER, 2012 b), is inserted, working toward the dialogue established between the media system, comprising devices such as television, newspapers, magazines etc. (SOSTER, 2009), along with other social systems, in order to produce, within the media's architecture, differences that establish differences. One example is the clear move the program makes in search of an "esthetizing" of the news, chiefly seen in the use of virtual resources via visual arts as regards form, and the appropriation of resources from literature as regards text composition. From this 
perspective, the mediatic system looks to literature for the substrate of its operations, absorbing logical sets inherent to literature as a way to obtain and offer differentiation.

Significantly, dialogy is a movement that has become increasingly common in this "dialogue" between fields of knowledge, based around the relativization of present-day conceptual limits. Following the consolidated narratives of modernity, the present moment is marked by hybridizations due to the erosion of boundaries between forms and ways of narrative. There is what Figueiredo (2010) calls a "slide" between narrative forms as a result of the various esthetics of today. For Machado (2010), this dialogy is present in the idea of "artmedia" proposed by the author. In other words, it is in the narrative hybridization between art and media that one finds contemporary esthetic opportunities to develop one's own narrative of invention.

The rise of the image in modern times - a resource capable of representing deep, abstract thinking in concise form (JAMESON, 1997) at a time of accelerated processes - is also responsible for the pursuit of the esthetization of news broadcasting. In the case of TV Folha, one notices the great esthetic care devoted to image and audio tracks used in the making of a show, especially in news reports. There is also a documentarytype narrative pace in major news stories that are characterized by indepth treatment and the search for various perspectives of a given event offered by several people interviewed (PICCININ, 2012 b). Photography framing, camera movement, edition and post production boasting simultaneously recurrent and elegant visual resources are offered in a movie-type rhythm. Further, expressive strategies of a clear esthetic sense are used in the audio-visual grammar (GAUDREAULT; JOST, 2009), pointing to this hybridization of journalism, be it as literary art, or with the fine arts.

\section{Final Considerations}

The analysis of TV Folha, carried out based on movements operated by mediatization in its four traits - self-reference, co-reference, decentralization and dialogy - points to the performance of news journalism faced with changes in conjuncture and structure, resulting in moving the medium from an adjacent position to a central one in modern times.

In that sense, reflections triggered by analysis of empirical reality based on the news broadcast program in question 
indicate that, in fact, understanding the reconfiguration of present-day news broadcasting requires constant movement - both dialectical and dialogical - between theoretical propositions and the "behavior" of news programs. By means of the changes discussed, ultimately, the news cast is the end-result of that integrative whole, a product of a gathering of the various media that comprise it, abandoning the traditional model encompassing merely the device of television. Following this rationale, the program changes in both form and content, as well as in its relation to the various social-techno-discursive instances, pushing for the creation of new protocols and new grammar which acknowledge its relation to what is conceptually understood as the news broadcast program in the changing scenario in modern times.

\section{NOTES}

1 Ethicity is understood here through Kilpp's perspective (2003), as the imaginary construed by the receptor based on the "framework" offered by television on the different programs that make up its grid. Or, in the words of the author: "(...) ethnicities designate virtual subjectivities (duration, personae, objects, facts and events that television offers to be seen as such, but that are, in fact, televisual constructs), whose identity senses (both ethical and esthetic) are activated in a mixture of frameworks and frameworking of images(...). (Kilpp: 2003, p.33).

2 TV Folha has been the object of research by author Fabiana Piccinin, who offered the first reflections on that program in the article "Tudo ao mesmo tempo e agora": análise da cobertura de cotidiano no TV Folha (Everything at the same time and now: an analysis of current events coverage on TV Folha), presented at the $10^{\text {th }}$ edition of SBPJor, at the coordinated table on News Broadcasting Journalism, in November 2012, in Curitiba. In the article in question, transformations in news broadcasting are observed via the technological and esthetic perspective by means of an analysis of the coverage of a specific story on the program: the occupation of a building in downtown São Paulo, aired on May 20, 2012. The news reports can be consulted at: http://www.youtube.com/watch?v=iYK5sBLpVjM and http://www.youtube.com/watch?v=RNW25XJIrFw\&feature=relmfu.

3 All news reports aired on the program to date are in individual links at http://www1.folha.uol.com.br/tv/programatvfolha/.The Folha Group, however, provides free access to a maximum of 40 viewings. Users need only register on the system. Payment is required for those seeking over 40 viewings.

"Reporter-bee" or videoreporter are terms used to refer to those reporters 
that carry out various functions when working on a story in television, such as filming, editing and sending material to the newsroom.

\section{REFERENCES}

BECKER, Beatriz; TEIXEIRA, Juliana. Narrativas jornalísticas audiovisuais: um estudo dos efeitos da convergência no JN e no UOL. Revista Galáxia. São Paulo, n. 18, p.232-246, dez. 2009.

BUSTAMANTE, Enrique. La televisión econômica. Financiación, estratégias y mercados. Barcelona: Gedisa Editorial, 1999. 379 p.

CABRAL, Águeda, VIZEU, Alfredo, MESQUITA, Giovana \& CIRNE, Lívia. Convergência e diálogo de sentidos no telejornalismo da Tv digital. Intercom - Sociedade Brasileira de Estudos Interdisciplinares da Comunicação XXXIV Congresso Brasileiro de Ciências da Comunicação - Recife, PE - 2 a 6 de setembro de 2011 . Available at: http ://www. intercom.org.br/papers/nacionais/2011/resumos/R6-2398-1.pdf. Accessed on: September 2012.

CANNITO, Newton. A televisão na era digital. São Paulo: Summus, 2010. 263 p.

CASTELLS, Manuel. A Sociedade em Rede. 7. ed., v. 1. São Paulo: Paz e Terra, 200.617 p.

DÁVILA, Sérgio. TV Folha" completa 3 meses com furos e histórias exclusivas. Available at: http://noticias.bol.uol.com.br/ entretenimento/2012/06/10/quottv-folhaquot-completa-3-mesescom-furos-e-historias-exclusivas.jhtm. Accessed on: July 2012.

FAUSTO NETO, Antonio. Narratividade jornalística no ambiente da circulação. In: Fabiana Piccinin; Demétrio de Azeredo Soster. (Org.) Narrativas comunicacionais complexificadas. Santa Cruz do Sul: Edunisc, 2012, v. 1, p. 46-67.

. Fragmentos de uma <<analítica>> da midiatização. MATRIZes. No 2/abril 2008 - São Paulo. P. 89-105.

. Mutações nos discursos jornalísticos: Da 'construção da realidade' à 'realidade da construção'. In: Ângela Felippi; Demétrio de Azeredo Soster; Fabiana Piccinin. (Org.). Edição em jornalismo: ensino, teoria e prática. Edição em jornalismo: ensino, teoria e prática. Santa Cruz do Sul: Edunisc, 2006, v. 1, p. 46-63.

FIGUEIREDO, Vera Lúcia Follain de. Narrativas migrantes: Literatura, 
roteiro e cinema. Rio de Janeiro: Ed. PUC-Rio: 7 Letras, 2010. 284 p.

GAUDREAULT, André \& JOST, François. A narrativa cinematográfica. Brasília: UnB, 2009. 227 p.

GOMES, Pedro Gilberto. Filosofia e Ética da Comunicação na

Midiatização da Sociedade. São Leopoldo: Unisinos, 2006. 143 p.

HJARVARD, Stig. Midiatização: teorizando a mídia como agente de mudança social e cultural. MATRIZes. Ano 5. N² 2/ jan./jun. 2012 São Paulo. Brasil. P. 53-91.

JAMESON, Frederic. Pós-modernismo. A lógica cultural do capitalismo tardio. 2. ed. São Paulo: Ática, 1997. 431 p.

JENKINS, Henry. Cultura da convergência. São Paulo: Aleph, 2008. $380 \mathrm{p}$.

KILPP, Suzana. Ethicidades televisivas. Sentidos identitários na Tv. São Leopoldo, 2003. 239 p.

LUHMANN, Niklas. Introdução à teoria dos sistemas. Rio de Janeiro: Vozes, 2009

MACHADO, Arlindo. Artemídia. 3. Ed. Rio de Janeiro: Zahar, 2010. 84 p.

PICCININ, Fabiana. Da ascensão do realismo como narrativa da experiência contemporânea. In: GAI, Eunice Piazza \& OLIVEIRA, Vera Lúcia (orgs.). Narrativas brasileiras contemporâneas em foco. Santa Maria: Edufsm, 2012.180 p. (a).

."Tudo ao mesmo tempo e agora": análise da cobertura

de cotidiano no TV Folha. SBPJor - Associação Brasileira de Pesquisadores em Jornalismo. $10^{\circ}$ Encontro Nacional de Pesquisadores em Jornalismo. Curitiba - Pontifícia Universidade Católica do Paraná - Novembro de 2012. (b).

SILVA, Fernando Firmino da. Mobilidade convergente: Abordagem sobre a prática e os estudos do jornalismo móvel. Revista Ícone. v. 11 n. 2 - dezembro de 2009. P. 1-18. Available at: http://www.iconeppgcom.com.br/index.php/icone/article/viewFile/57/53. Accessed September 2012.

SOSTER, Demétrio de Azeredo. Telewebjornalismo, entre autonomia e o outsourcing. In: FELIPPI, Ângela, PICCININ, Fabiana \& SOSTER, Demétrio de Azeredo. Edição de imagens em Jornalismo. Santa Cruz do Sul: Edunisc, 2008. 255 p.

O jornalismo em novos territórios conceituais: internet, midiatização e a reconfiguração dos sentidos midiáticos. Programa 
de Pós-Graduação em Ciências da Comunicação 2009. 185 f. Tese (Doutorado) - Universidade do Vale do Rio dos Sinos, 2009.

Jornalismo e literatura: narrativas reconfiguradas. In: GAI, Eunice Piazza \& OLIVEIRA, Vera Lúcia de (orgs.). Narrativas brasileiras contemporâneas. Santa Maria: UFSM, 2012 (a). 179 p.

Sistemas, complexidades e dialogias: narrativas jornalísticas reconfiguradas. In: PICCININ, Fabiana \& SOSTER, Demétrio de Azeredo (orgs). Narrativas comunicacionais complexificadas. Santa Cruz do Sul: Edunisc, 2012 (b). (no prelo).

SODRÉ, Muniz. Antropológica do espelho. 2. Ed. Vozes: Petrópolis, 2006. 268 p. 
THE ANATOMY OF MEDIATIZED NEWS BROADCASTING

BRAZILIAN JOURNALLSM RESEABCH-Volume 8-number z- zOIa| 131 